\title{
Perancangan Sistem Pelayanan Informasi Berbasis Android dengan Algoritma Nazief Andriani (Studi Kasus : Universitas Katolik Santo Thomas)
}

\author{
Ita Juwita Saragih ${ }^{* 1}$, Zakarias Situmorang ${ }^{2}$ \\ ${ }^{1,2}$ Universitas Katolik Santo Thomas, Jl. Setiabudi No. 479 F Tanjungsari, Medan-Indonesia. \\ ita.juwita.saragih@gmail.com ${ }^{1}$,zakarias65@yahoo.com ${ }^{2}$
}

\begin{abstract}
Abstrak-Pelayanan merupakan sutau usaha untuk membantu menyiapkan (mengurus) apa yang diperlukan orang lain. Atau dapat diartikan bahwa pelayanan adalah serangkaian kegiatan atau proses pemenuhan kebutuhan orang lain secara lebih memuaskan. Untuk mempermudah pelayanan yang ada di Universitas Katolik Santo Thomas maka perlu dibangun sebuah sistem pelayanan informasi berbasis android dengan algoritma nazief andriani. Algoritma ini mampu mencari kata dasar dari masing-masing input sehingga dapat mengasilkan output yang terpisah atau dengan kata lain output yang dikeluarkan tepat pada sasaran atau pada tujuan. Dengan adanya sistem ini maka mahasiswa tidak perlu lagi datang ke unit tata usaha atau via chat untuk mendapatkan informasi mengenai kegiatan atau keluhan yang diterima atau yang ingin disampaikan. Sehingga sistem ini diharapkan dapat mempermudah pengguna untuk mendapatkan informasi yang akurat, efisien dan tidak membutuhkan waktu yang relatif lama sehingga menyebabkan pelayanan yang lambat, terbatas dan tidak responsif dalam memberikan jawaban.
\end{abstract}

Kata kunci: Algoritma nazief andriani, Android.

Abstract-Service is an effort to help prepare what others need. Or it can be interpreted that service is a series of activities or processes that fulfill the needs of others more satisfactorily. To simplify the services available at the Catholic University of Santo Thomas, it is necessary to build an android-based information service system with Nazief Andriani algorithm. This algorithm is able to find the basic words of each input so that it can produce a separate output or in other words the output issued right on target or on purpose. With this system, students no longer need to come to the administrative unit or via chat to get information about activities or complaints that are received or what they want to convey. So that this system is expected to make it easier for users to get accurate, efficient information and does not require a relatively long time, causing slow, limited and unresponsive service in providing answers.

Keywords: Andriani Nazief algorithm, Android.

\section{PENDAHULUAN}

Pada sistem pelayanan informasi yang akan dibangun ini menggunakan metode algoritma Nazief Andriani dimana algoritma Nazief Andriani ini berdasarkan pada aturan morfologi bahasa Indonesia yang luas, yang dikumpulkan menjadi satu grup dan di-enkapsulasi pada imbuhan/affixes yang diperbolehkan (allowed affixes) dan imbuhan/affixes yang tidak diperbolehkan (disallowed affixes). Algoritma ini menggunakan kamus kata dasar dan mendukung recoding, yakni penyusunan kembali kata-kata yang mengalami proses stemming berlebih [1]. Algoritma ini mampu mencari nilai bobot peran dari masing masing input sehingga dapat menghasilkan output yang terpisah atau dengan kata lain output yang di keluarkan tepat pada sasaran atau pada tujuan. Salah satu implementasi dari algoritma Nazief-Adriani yaitu untuk menyampaikan informasi sampai ke user jika ada keluhan, pelayanan, dan informasi kemahasiswa dengan universitas [2], [3].

Universitas Katolik Santo Thomas memiliki tujuh fakultas yaitu fakultas ilmu komputer, fakultas ekonomi, fakultas hukum, fakultas teknik, fakultas sastra, fakultas keguruan dan ilmu pendidikan, dan fakultas pertanian. Universitas Katolik Santo Thomas memiliki elemen yang mendukung proses Kegiatan Belajar Mengajar (KBM), yakni mahasiswa, dosen, kurikulum, dan sarana serta prasarana pendukung lainnya dan dimana sistem pelayanan sangat berperan supaya segala kegiatan dapat berjalan dengan baik[4].

Pelayan yang ada pada Universitas Katolik Santo Thomas khususnya di program studi Teknik

Informatika pada umumnya masih manual dan membutuhkann waktu yang relatif lama sehingga menyebabkan pelayanan yang lambat, terbatas, dan tidak responsif dalam memberikan jawaban. Dosen, pegawai, dan mahasiswa harus datang ke unit tata usaha atau via chat untuk mendapatkan informasi mengenai kegiatan atau keluhan yang diterima atau yang ingin disampaikan. Untuk meningkatkan layanan informasi diperlukan upaya perbaikan sistem dengan melakukan pengembangan jenis layanan dan kapasitas layanan. Sistem pelayanan informasi ini dapat melayani kebutuhan dosen, pegawai, mahasiswa [5].

Layanan ini akan menjadi salah satu bentuk fasilitas dari universitas untuk memberikan kemudahan dan kenyamanan bagi para pengguna. Penerapan penggunaan sistem pelayanan informasi disebuah universitas saat ini menjadi suatu kebutuhan wajib supaya dapat meningkatkan daya saing perguruan tinggi. Dengan kemampuan sistem pelayanan informasi yang dapat menghasilkan informasi yang akurat, cepat, dan efisien akan memberikan manfaat yang sangat besar dengan kriteria kemampuan yang dapat memenuhi harapan penggunanya. Kesuksesan sistem pelayanan informasi merupakan suatu tingkat dimana sistem pelayanan ini mampu memberikan konstribusi dalam pencapaian tujuan. Sebaliknya dikatakan gagal apabila 
sistem pelayanan tersebut kurang atau bahkan tidak dimanfaatkan oleh penggunanya. Agar suatu sistem pelayanan informasi dapat beroperasi secara optimal, perlu adanya evaluasi terhadap sistem layanan informasi [6], [7].

Algoritma Nazief \& Adriani dikembangkan pertama kali oleh Bobby Nazief dan Mirna Adriani. Algoritma ini berdasarkan pada aturan morfologi bahasa Indonesia yang luas, yang dikumpulkan menjadi satu grup dan di-enkapsulasi pada imbuhan/affixes yang diperbolehkan (allowed affixes) dan imbuhan/affixes yang tidak diperbolehkan (disallowed affixes). Algoritma ini menggunakan kamus kata dasar dan mendukung recoding, yakni penyusunan kembali kata-kata yang mengalami proses stemming berlebih[1], [8].

Konsep dasar pelayanan disepenisikan juga oleh banyak pakar. Pelayanan sebagai "suatu usaha untuk membantu menyiapkan (mengurus) apa yang diperlukan orang lain. Atau dapat diartikan bahwa pelayanan adalah serangkaian kegiatan atau proses pemenuhan kebutuhan orang lain secara lebih memuaskan berupa produk jasa dengan sejumlah ciri seperti tidak terwujud, cepat hilang, lebih dapat dirasakan daripada dimiliki dan pelanggan lebih dapat berpartisipasi aktif dalam mengkonsumsi jasa tersebut. Sedangkan definisi yang paling rinci sebagaimana yang dikutip bahwa pelayanan adalah suatu aktivitas atau serangkaian aktivitas yang bersifat tidak kasat mata (tidak dapat diraba) yang terjadi sebagai adanya akibat interaksi antara konsumen dengan karyawan atau hal-hal lain yang disediakan oleh perusahaan pemberi pelayanan yang dimaksut untuk memecahkan permasalahan kosumen/pelanggan"[9].

Berdasarkan penjelasan diatas maka penulis tertarik untuk menulis judul penelitian "Perancangan sistem pelayanan informasi berbasis android dengan algoritma Nazief Andriani (Studi kasus: Universitas Katolik Santo Thomas)" dimana sistem pelayanan ini akan mempermudah pengguna untuk mendapatkan informasi yang akurat, efisien, dan tidak akan membutuhkan waktu yang relatif lama sehingga menyebabkan pelayanan yang lambat, terbatas, dan tidak responsif dalam memberikan jawaban.

\section{METODE PENELITIAN}

Adapun tahapan penelitian yang dilaksanakan dalam penelitian R\&D ini adalah[10]:

1. Pengumpulan Data.

a. Studi Kepustakaan yaitu penelusuran informasi kepustakaan dalam sistem pelayanan informasi berbasis android maupun tentang analisis kelayakan proyek secara umum.

b. Wawancara dan Observasi, mencari dan mengumpulkan data, dimana data-data yang ada relevansinya dengan judul tugas akhir.

2. Pengembangan Sistem Pelayanan Informasi

a. Tahap perencanaan

Proses dilaksanakan, meliputi kegiatan identifikasi masalah, tujuan dari sistem pelayanan informasi, dan menyusun studi kelayakan.

b. Tahap Analisis

Tahapan selanjutnya adalah menganalisa permasalahan dan mencari solusi serta rencana-rencana dalam penggambangan sistem pelayanan informasi berbasis android.

c. Tahap Rancangan

Setelah memahami masalah dan mencari solusi serta memahami kebutuhan pengguna, tahap selanjutnya adalah mendesain sistem pelayanan informasi agar sesuai dengan prosedur yang telah dibuat sebelumnya, dan diharapkan mengatasi masalah yang ada di Universitas Katolik Santo Thomas.

d. Tahap Pengujian Metode

Algoritma Nazief \& Adriani dikembangkan pertama kali oleh Bobby Nazief dan Mirna Adriani. Algoritma ini berdasarkan pada aturan morfologi bahasa Indonesia yang luas, yang dikumpulkan menjadi satu grup dan di-enkapsulasi pada imbuhan/affixes yang diperbolehkan (allowed affixes) dan imbuhan/affixes yang tidak diperbolehkan (disallowed affixes). Algoritma ini menggunakan kamus kata dasar dan mendukung recoding, yakni penyusunan kembali kata-kata yang mengalami proses stemming berlebih [8].

Algoritma yang dibuat oleh Bobby Nazief dan Mirna Adriani memiliki tahapan sebagai berikut[2]:

1. Cari kata yang akan distem dalam kamus. Jika ditemukan maka diasumsikan bahwa kata tesebut adalah root word. Maka algoritma berhenti. 
2. Inflection Suffixes(“-lah”, “-kah”, “-ku”, “-mu”, atau “-nya”) dibuang. Jika berupa particles (“lah", "-kah", "-tah" atau "-pun") maka langkah ini diulangi lagi untuk menghapus Possesive Pronouns("-ku", "-mu", atau "-nya"), jika ada.

3. Hapus Derivation Suffixes("-i", "-an" atau "-kan"). Jika kata ditemukan di kamus, maka algoritma berhenti. Jika tidak maka ke langkah $3 \mathrm{a}$

a. Jika "-an" telah dihapus dan huruf terakhir dari kata tersebut adalah "-k", maka "-k" juga ikut dihapus. Jika kata tersebut ditemukan dalam kamus maka algoritma berhenti. Jika tidak ditemukan maka lakukan langkah $3 b$.

b. Akhiran yang dihapus ("-i", "-an" atau "-kan") dikembalikan, lanjut kelangkah 4.

4. Hapus derivational prefix (awalan turunan). Hilangkan awalan be-, di-, ke-, me-, pe-, se- dan te-.

a. Langkah 4 ini jangan dilakukan bila: $\rightarrow$ kata dalam langkah 3, mempunyai gabungan awalan dan imbuhan yang tidak diperbolehkan. Contoh awalan dan imbuhan yang tidak diperbolehkan yaitu:

ber- -i

di- -an

ke- -i -kan

me- -an

ter- -an

per- -an

$\rightarrow$ awalan yang akan dihilangkan, sama dengan awalan yang telah dihilangkan sebelumnya $\rightarrow$ awalan telah dihilangkan sebanyak tiga kali

b. Identifikasi tipe awalan dan disambiguitasnya.Awalan mempunyai dua tipe:plain: awalan di-, ke-, se- dapat dihilangkan secara langsungcomplex: awalan be-, te-, me-, pe- harus dianalisis ambiguitasnya menggunakan tabel diambiguitas di bawah. Awalan me- bisa berubah mem- atau men- tergantung dari huruf awal akar kata, seperti di bawah ini:

\begin{tabular}{|c|c|c|}
\hline Rule & Construct & Return \\
\hline 1 & berV... & ber-V... | be-rV ... \\
\hline 2 & berCAP... & ber-CAP... | where C!='r' and P!='er' \\
\hline 3 & berCAerV... & ber-CAerV... | where C!='r' \\
\hline 4 & belajar... & bel-ajar... \\
\hline 5 & beC1erC2... & be-C1erC2 $\ldots \mid$ where $\mathrm{C} 1 !=\{$ ' $r$ '| ' 1 ' $\}$ \\
\hline 6 & terV $\ldots$ & ter-V... te-rV ... \\
\hline 7 & terCerV ... & ter-CerV ... | where C!='r' \\
\hline 8 & terCP... & ter-CP... where C!='r' and P!='er' \\
\hline 9 & teC1erC2... & te-C1erC2... where $\mathrm{C} 1$ !='r' \\
\hline 10 & $\operatorname{me}\{1|\mathrm{r}| \mathrm{w} \mid \mathrm{y}\} V \ldots$ & $\operatorname{me}-\{1|\mathrm{r}| \mathrm{w} \mid \mathrm{y}\} \mathrm{V} \ldots$ \\
\hline 11 & $\operatorname{mem}\{b|f| v\} \ldots$ & $\operatorname{mem}-\{\mathrm{b}|\mathrm{f}| \mathrm{v}\} \ldots$ \\
\hline 12 & mempe $\{r \mid 1\} \ldots$ & mem-pe... \\
\hline 13 & $\operatorname{mem}\{r \mathrm{rV} \mid \mathrm{V}\} \ldots$ & me-m $\{r V \mid V\} \ldots \mid$ me-p $\{r V \mid V\} \ldots$ \\
\hline 14 & $\operatorname{men}\{\mathrm{c}|\mathrm{d}| \mathrm{j} \mid \mathrm{z}\} \ldots$ & men- $\{\mathrm{c}|\mathrm{d}| \mathrm{j} \mid \mathrm{z}\} \ldots$ \\
\hline 15 & menV... & me-nV ... me-tV... \\
\hline 16 & meng $\{g|\mathrm{~h}| \mathrm{q}\} \ldots$ & meng- $\{\mathrm{g}|\mathrm{h}| \mathrm{q}\} \ldots$ \\
\hline 17 & mengV... & meng-V ... meng-kV ... \\
\hline 18 & menyV... & meny-sV ... \\
\hline
\end{tabular}




\section{9}

20

21

23

24

25

26

27

28

29

30

31

32

34

$$
\begin{aligned}
& \operatorname{mempV} \ldots \\
& \text { pe }\{\mathrm{w} \mid \mathrm{y}\} \mathrm{V} \ldots \\
& \text { perV ... } \\
& \text { perCAP ... } \\
& \text { perCAerV ... } \\
& \operatorname{pem}\{\mathrm{b}|\mathrm{f}| \mathrm{v}\} \ldots \\
& \operatorname{pem}\{\mathrm{rV} \mid \mathrm{V}\} \ldots \\
& \operatorname{pen}\{\mathrm{c}|\mathrm{d}| \mathrm{j} \mid \mathrm{z}\} \ldots \\
& \operatorname{pen} \mathrm{\ldots} \ldots \\
& \operatorname{peng}\{\mathrm{g}|\mathrm{h}| \mathrm{q}\} \ldots \\
& \operatorname{pengV} \ldots \\
& \operatorname{penyV} \ldots \\
& \operatorname{pelV} \ldots \\
& \operatorname{peCerV} \ldots \\
& \operatorname{peCP} \ldots
\end{aligned}
$$

Keterangan :

$\mathrm{V}=$ Vokal

$\mathrm{C}=$ Consonan

$\mathrm{P}=$ Bagian kata misalnya "er"

5. Melakukan Recoding.

6. Jika semua langkah telah selesai tetapi tidak juga berhasil maka kata awal diasumsikan sebagai root word. Proses selesai.

Tipe awalan ditentukan melalui langkah-langkah berikut:

1. Jika awalannya adalah: "di-", "ke-", atau "se-" maka tipe awalannya secara berturut-turut adalah "di-", "ke-", atau "se-".

2. Jika awalannya adalah "te-", "me-", "be-", atau "pe-" maka dibutuhkan sebuah proses tambahan untuk menentukan tipe awalannya.

3. Jika dua karakter pertamabukan "di-","ke-","se-","te-", "be-", "me-", atau "pe-" maka berhenti.

4. Jika tipe awalan adalah "none" maka berhenti. Jika tipe awalan adalah bukan "none".

Dalam penelitiannya Asian, dkk (Asian et al., 2005) dalam (Dwi Wahyudi, Dkk) melakukan beberapa pengembangan algoritma Nazief \& Adriani sebagai berikut:

1. Menggunakan kamus kata yang lebih lengkap

2. Menambahkan aturan-aturan untuk kata-kata majemuk perulangan.

3. Menambahkan aturan awalan dan akhiran, serta aturan lainnya, yaitu:

a. Menambahkan partikel (inflection suffix) "-pun".

b. Penambahan aturan pemenggalan awalan.

c. Perubahan aturan pemenggalan untuk tipe awalan "me".

4. Perubahan urutan proses stemming, yaitu:

a. Kata dengan awalan "be-" dan akhiran "-lah", hilangkah awalan terlebih dahulu kemudian akhiran.

b. Kata dengan awalan "be-" dan akhiran "-an", hilangkan awalan terlebih dahulu kemudian akhiran.

c. Kata dengan awalan "me-“ dan akhiran "i", hilangkan awalan terlebih dahulu kemudian akhiran.

d. Kata dengan awalan "di-“ dan akhiran "-i”, hilangkan awalan terlebih dahulu kemudian akhiran. 
e. Katadengan awalan "pe-“ dan akhiran "-i”, hilangkan awalan terlebih dahulu kemudian akhiran.

f. Kata dengan awalan "ter-" dan akhiran "-i", hilangkan awalan terlebih dahulu kemudian akhiran.

\subsection{Analisis Sistem Baru}

\section{HASIL DAN PEMBAHASAN}

Sistem yang akan dibuat merupakan sistem pusat pelayanan, baik berupa informasi maupun keluhan di Universitas Katolik Santo Thomas. Sistem ini berguna untuk membantu dosen/pegawai dan mahasiswa untuk mendapatkan informasi maupun memberikan keluhan tanpa harus bertemu langsung dengan orang yang bersangkutan. Contohnya di Universitas Katolik Santo Thomas pada saat ini jika dosen/pegawai dan mahasiswa ingin mendapatkan informasi atau memberikan keluhan harus datang ke unit tata usaha atau via chat. Dengan adanya sistem pelayanan informasi yang akan dibangun ini maka mahasiswa dosen/pegawai tidak perlu lagi datang ke unit tata usaha atau via chat untuk mendapatkan informasi atau memberikan keluhan.

Pada sistem pelayanan informasi yang akan dibangun ini menggunakan metode algoritma Nazief Andriani dimana algoritma Nazief Andriani ini berdasarkan pada aturan morfologi bahasa Indonesia yang luas, yang dikumpulkan menjadi satu grup dan di-enkapsulasi pada imbuhan/affixes yang diperbolehkan (allowed affixes) dan imbuhan/affixes yang tidak diperbolehkan (disallowed affixes). Algoritma ini menggunakan kamus kata dasar dan mendukung recoding, yakni penyusunan kembali kata-kata yang mengalami proses stemming berlebih. Algoritma ini mampu mencari kata dasar dari masing masing input sehingga dapat menghasilkan output yang terpisah atau dengan kata lain output yang di keluarkan tepat pada sasaran atau pada tujuan. Adapun konsep sistem yang akan dibangun dalam memberikan keluhan ataupun menyampaikan informasi seperti gambar 1 di bawah ini.

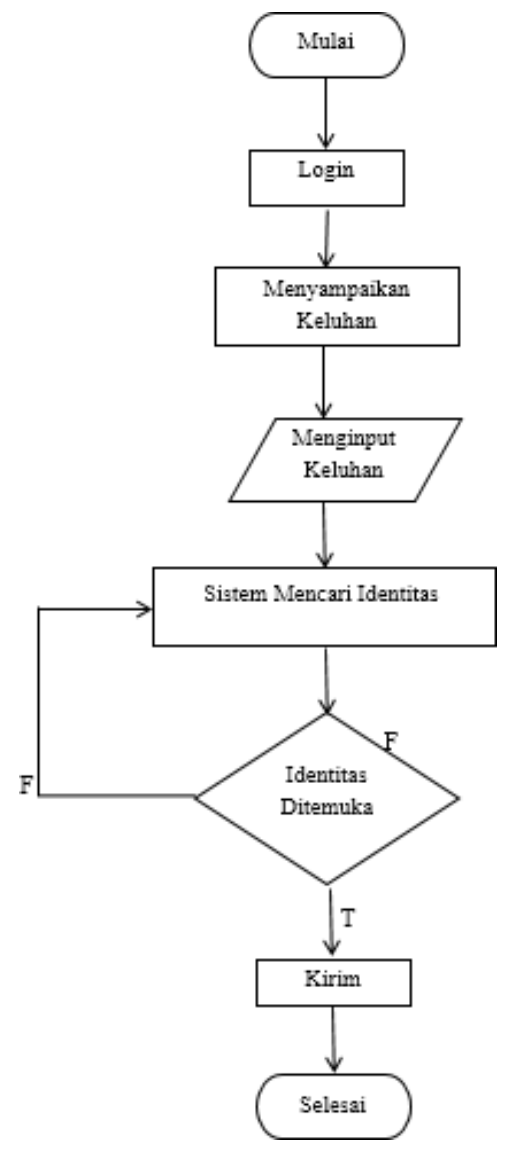

Gambar 1. Flowchart Analisis Sistem

Pada gambar 1 di atas flowchart analisis sistem dapat dijelaskan bahwa jika ingin menyampaikan keluhan makan sistem yang akan dibangun akan secara otomatis mencari identitas tujuan dan jika tidak di temukan maka sistem akan mencari ulang identitas tujuan. 
Tujuan utama dari contoh kasus metode Nazief Andriani ini yaitu memberikan gambaran umum proses kerja dari metode nazief andriani. Adapun beberapa contoh proses metode Nazief Andriani yaitu [11]:

1. Stamming : Tembusan menjadi tembus

Adapun langkah-langkahnya sebagai berikut:

a. Pertama cek kata tembusan di kamus database. Kata tembusan tidak ditemukan pada database, lanjut ke langkah $b$.

b. Menghilangkan inflectional suffix (imbuhan infleksional) dengan cara menghilangkan imbuhan kah, -lah, -pun kemudian hilangkan imbuhan -ku, -mu, -nya. Pada kata tembusan tidak terdapat imbuhan tersebut sehingga hasilnya masih kata tembusan. Cek kata tembusan di kamus database. Kata tembusan tidak ditemukan, lanjut ke langkah c.

c. Hilangkan derivational suffix (imbuhan turunan) dengan cara menghilangkan imbuhan -i, -kan, -an. Pada kata tembusan terdapat imbuhan turunan yaitu -an sehingga hasilnya menjadi tembus. Cek kata tembus didatabase, kata tembus ditemukan pada database. Proses algoritma berhenti.

2. Stamming : Pemrosesan menjadi proses

Adapun langkah-langkahnya sebagai berikut:

a. Pertama cek kata pemrosesan di kamus database. Kata pemrosesan tidak ditemukan pada database, lanjut ke langkah $b$.

b. Menghilangkan inflectional suffix (imbuhan infleksional) dengan cara menghilangkan imbuhan kah, -lah, -pun kemudian hilangkan imbuhan -ku, -mu, -nya. Pada kata pemrosesan tidak terdapat imbuhan tersebut sehingga hasilnya masih kata pemrosesan. Cek kata pemrosesan di kamus database. Kata pemrosesan tidak ditemukan, lanjut ke langkah c.

c. Hilangkan derivational suffix (imbuhan turunan) dengan cara menghilangkan imbuhan -i, -kan, -an. Pada kata pemrosesan terdapat imbuhan turunan yaitu -an sehingga hasilnya menjadi pemroses. Cek kata pemroses dikamus database, kata pemroses tidak ditemukan. Lanjut ke langkah d.

d. Hilangkan derivational prefix (awalan turunan) dengan cara menghilangkan awalan be-, di-, ke-, me, pe-, se-, dan te-. Pada kata pemroses ditemukan awalan turunan yaitu pe. Jika awalan tersebut ditemukan maka dilakukan identipikasi tipe awalan dan disambiguitasnya:

Awalan mempunyai dua tipe :

Plain : awalan di-, ke-, se-, dapat dihilangkan secara langsung

Complex : awalan be-, te-, me-, pe-, harus dianalisis ambiguitasnya menggunkan tabel diambiguita.

4.1 Kata Pemroses ditemukan awalan turunan yaitu pe.

4.2 Pada tabel diambiguitas jika "pe" di temukan maka aturan yang berlaku yaitu akan dikembalikan dua kata yaitu mroses dan proses.

Kata mroses di cek di database, tidak ditemukan. cek kata proses di database, kata proses ditemukan. Algoritma berhenti.

3. Satmming : Penipu menjadi tipu

Adapun langkah-langkahnya sebagai berikut:

a. Pertama cek kata penipu di kamus database. Kata penipu tidak ditemukan pada database, lanjut ke langkah $b$.

b. Menghilangkan inflectional suffix (imbuhan infleksional) dengan cara menghilangkan imbuhan kah, -lah, -pun kemudian hilangkan imbuhan -ku, -mu, -nya. Pada kata penipu tidak terdapat imbuhan tersebut sehingga hasilnya masih kata penipu. Cek kata penipu di kamus database. Kata penipu tidak ditemukan, lanjut ke langkah c.

c. Hilangkan derivational suffix (imbuhan turunan) dengan cara menghilangkan imbuhan -i, -kan, -an. . Pada kata penipu tidak terdapat imbuhan tersebut sehingga hasilnya masih kata penipu. Cek kata penipu di kamus database. Kata penipu tidak ditemukan. Lanjut ke langkah d.

d. Hilangkan derivational prefix (awalan turunan) dengan cara menghilangkan awalan be-, di-, ke-, me, pe-, se-, dan te-. Pada kata penipu ditemukan awalan turunan yaitu pe. Jika awalan tersebut ditemukan maka dilakukan identifikasi tipe awalan dan disambiguitasnya:

Awalan mempunyai dua tipe :

Plain : awalan di-, ke-, se-, dapat dihilangkan secara langsung

Complex : awalan be-, te-, me-, pe-, harus dianalisis ambiguitasnya menggunkan tabel diambiguita. 
$\rightarrow$ Kata penipu ditemukan awalan turunan yaitu pe.

$\rightarrow$ Pada tabel diambiguitas jika "pe" di temukan maka aturan yg berlaku yaitu akan di kembalikan dua kata yaitu "nipu" dan "tipu". Kata nipu di cek di database, tidak ditemukan, cek kata tipu di database, kata tipu ditemukan. Algoritma berhenti.

Keyword (kata kunci) adalah suatu susunan kata yang sering diketikkan untuk melakukan pencarian data atau informasi yang dibutuhkan. Adapun contoh beberapa keyword seperti di bawah ini:

Tabel 1. Tabel Keyword [11]

\begin{tabular}{|l|l|l|l|l|l|l|}
\hline $\begin{array}{l}\text { Keyword } \\
\text { Kaprodi }\end{array}$ & $\begin{array}{l}\text { Keyword } \\
\text { Bagian } \\
\text { Keuangan }\end{array}$ & $\begin{array}{l}\text { keyword } \\
\text { akademik }\end{array}$ & $\begin{array}{l}\text { Keyword } \\
\text { BAU }\end{array}$ & $\begin{array}{l}\text { Keyword } \\
\text { Asrama }\end{array}$ & $\begin{array}{l}\text { Keyword } \\
\text { Perpustakaan }\end{array}$ & $\begin{array}{l}\text { Keyword } \\
\text { Kemahasiswaan }\end{array}$ \\
\hline Seminar & akhir & Belajar & Cs & peraturan & buka & Alumni \\
\hline Jadwal & uang & Dosen & Scurty & acara & tutup & tahun \\
\hline Giat & bayar & jumlah & Fasilitas & kegiatan & buku & tamatan \\
\hline Biaya & cicil & Sks & Kerja & denda & judul & kegiatan \\
\hline Aktivitas & denda & Total & Gaji & cicil & Lama & izin \\
\hline Acara & batas & jadwal & dosen & tahun & denda & surat \\
\hline Kaprodi & sampai & waktu & Ruang & bulan & terakhir & teladan \\
\hline kurikulum & tutup & akademik & Kampus & uang & Buat & prestasi \\
\hline Berkas & tanggal & kurikulum & Jumlah & bayar & daftar & beasiswa \\
\hline Acc & sks & & Waktu & lemari & peserta & fasilitas \\
\hline Judul & persen & & Kapan & selimut & kartu & mahasiswa \\
\hline Skripsi & ukp & & wisuda & enak & kembali & informasi \\
\hline Waktu & semester & & Biaya & ada & pinjam & bagian \\
\hline & & & Bayar & kamar & sangsi & buka \\
\hline pembimbing & biaya & & acara & pedas & & tutup \\
\hline Dosen & daftar & & Mulai & makan & & \\
\hline & jumlah & & & & & \\
\hline & cetak & & & & & \\
\hline & total & & & & & \\
\hline
\end{tabular}

Use Case berfungsi untuk menggambarkan secara grafis perilaku software aplikasi atau menggambarkan fungsionalitas yang diharapkan dari sebuah sistem.

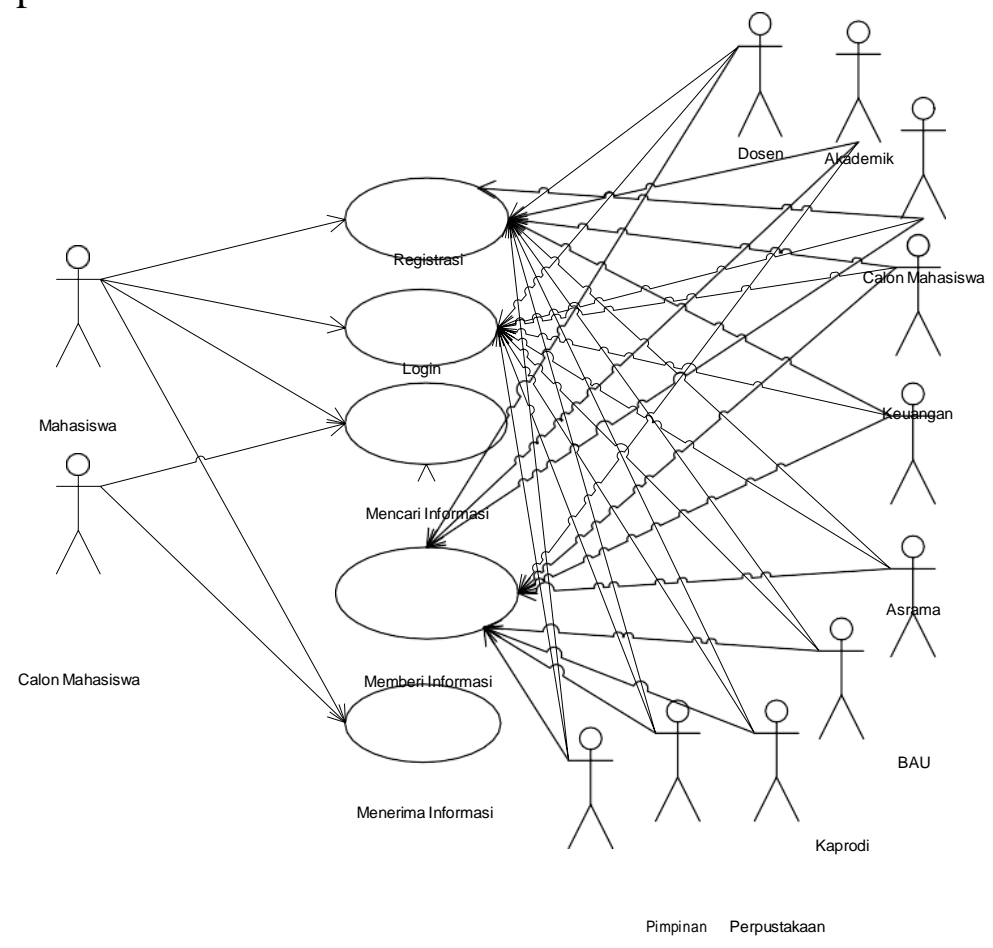

Kemahasiswaan 
Gambar 2. Diagram Use Case 


\subsection{Implementasi Antar Muka}

Implementasi antar muka Sistem Pelayanan Informasi berbasis Android Dengan Algoritma Nazief Andriani (Studi kasus: Universitas Katolik Santo Thomas) yang dibangun terdapat sebelas hak akses yang dapat menggunakan sistem, yaitu mahasiswa, akademik, keuangan, kaprodi, dosen, calon mahasiswa, perpustakaan, kemahasiswaan, BAU, asrama dan pimpinan. Setiap halaman dijabarkan sebagai beriku:

Halaman menuu utama merupakan tampilan awal setelah sistem dijalankan, dimana pada halaman menu utama terdapat beranda, tentang, registrasi dan login. Gambar halaman menu utama dapat dilihat pada gambar 3 di bawah ini.

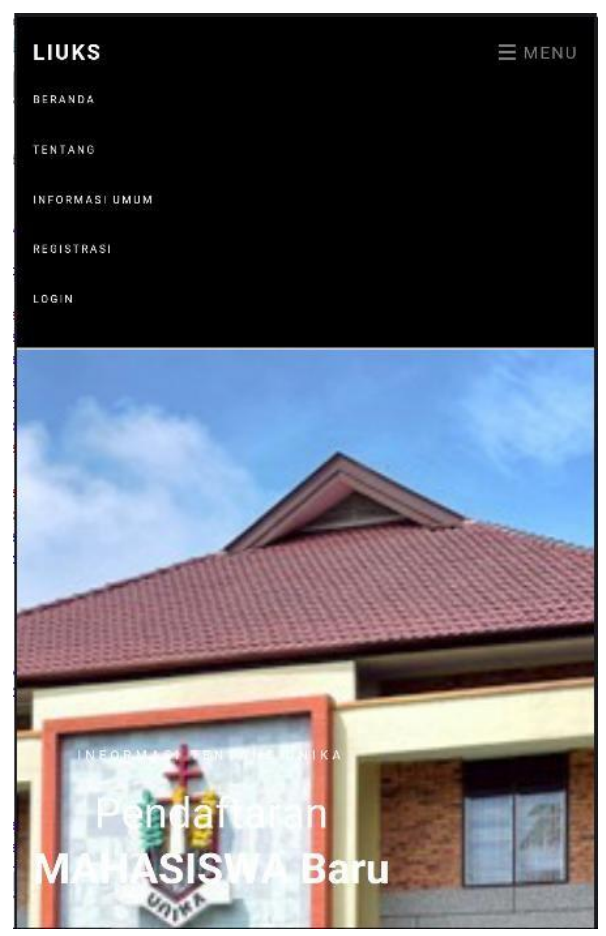

Gambar 3. Halaman Menu Utama

Halaman utama mahasiswa merupakan halaman untuk memberikan keluhan atau menerima informasi. Gambar halaman utama mahasiswa dapat dilihat pada gambar 4 di bawah ini.

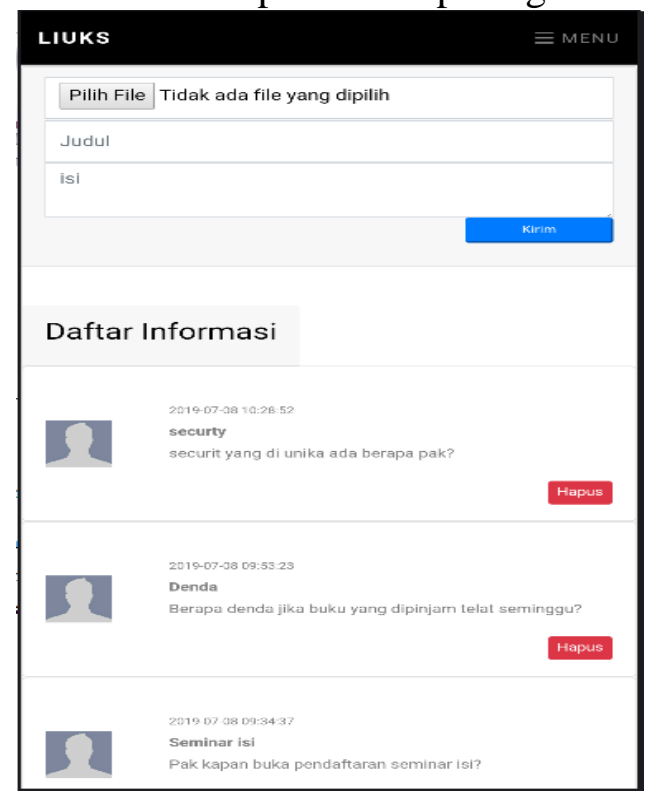

Gambar 4. Halaman Utama Mahasiswa

Halaman utama kemahasiswaan merupakan halaman menerima keluhan dan memberikan informasi seputar bagian kemahasiswaan. Gambar halaman utama kemahasiswaan dapat dilihat pada gambar 5 di bawah ini. 


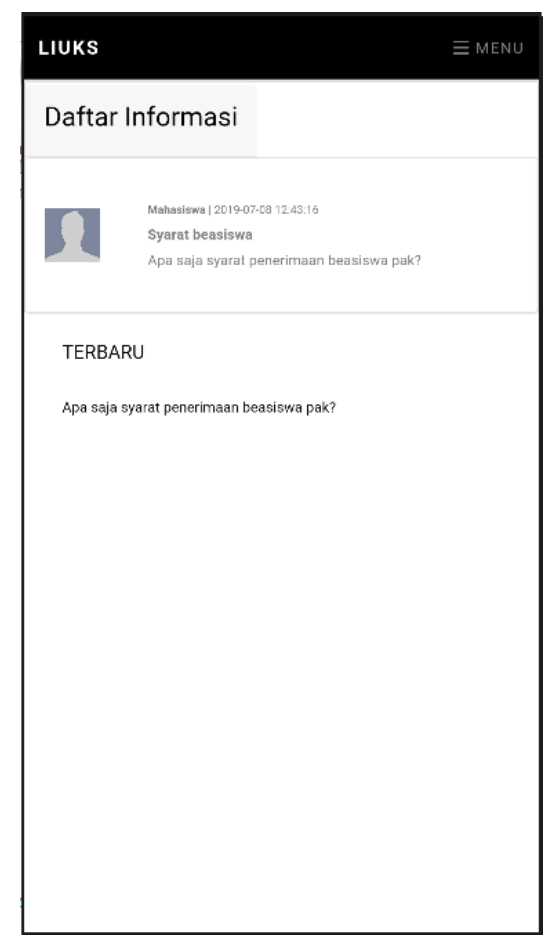

Gambar 5. Halaman Utama Kemahasiswaan

Halaman utama BAU merupakan halaman menerima keluhan dan memberikan informasi seputar bagian BAU. Gambar halaman utama BAU dapat dilihat pada gambar 6 di bawah ini.

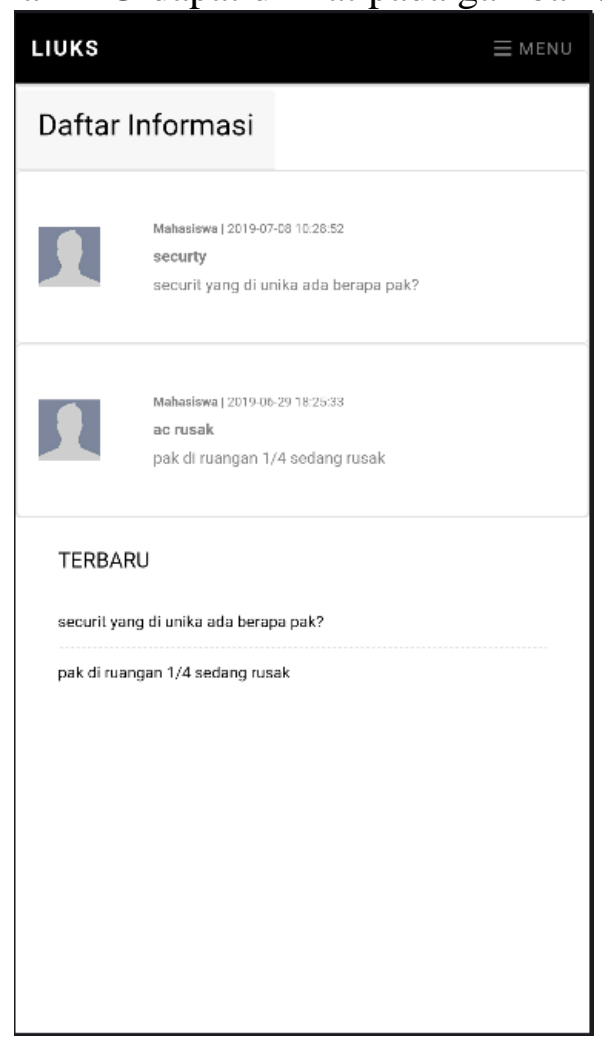

\section{Gambar 6. Halaman Utama BAU}

Halaman utama pimpinan merupakan halaman untuk melihat aktivitas-aktivitas dari masing masing bagian. Halaman menu utama pimpinan juga dapat melihat tanggal terakhir pesan dibalas oleh masing masing bagian dan pimpinan juga dapat mengambil alih untuk membalas pesan yang belum dibalas oleh masing-masing bagian. Gambar halaman utama pimpinan dapat dilihat pada gambar 7 di bawah ini. 


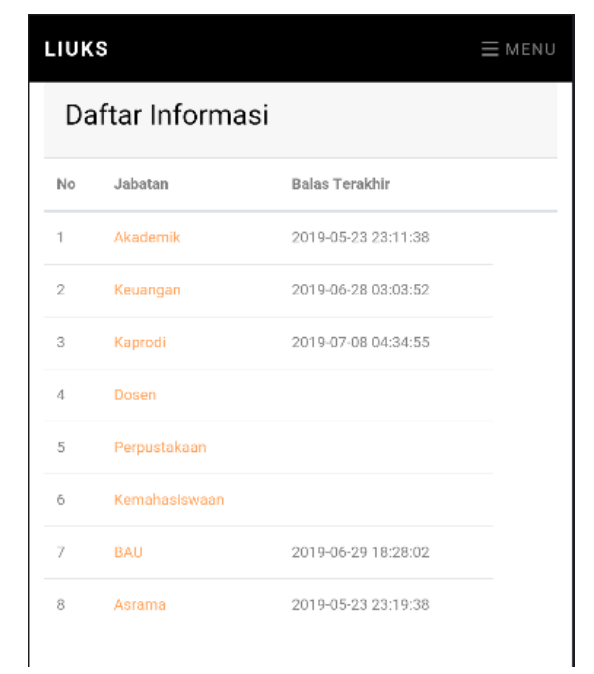

Gambar 7. Halaman Utama Pimpinan

Gambar untuk melihat total pesan yang belum dibalas dapat dilihat pada gambar 8 di bawah ini.

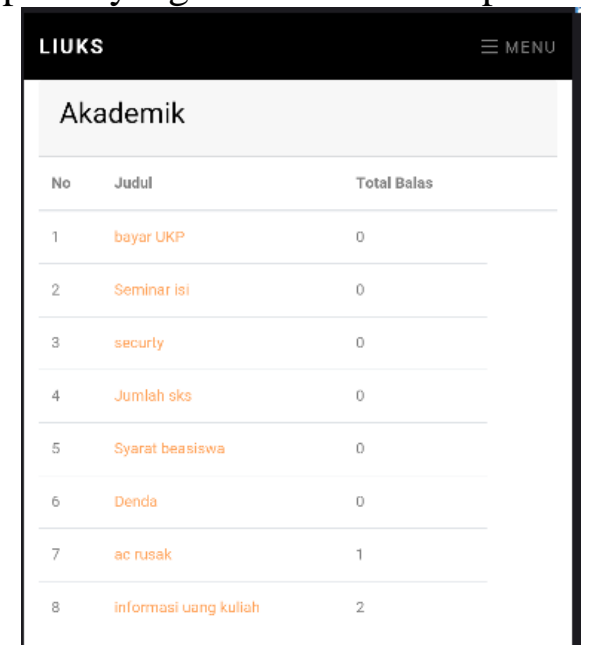

Gambar 8. Halaman Total Balasan

Halaman utama admin merupakan halaman untuk menginput informasi yang dapat dilihat di halaman informasi umum. Gambar halaman utama admin dapat dilihat pada gambar 9 di bawah ini.

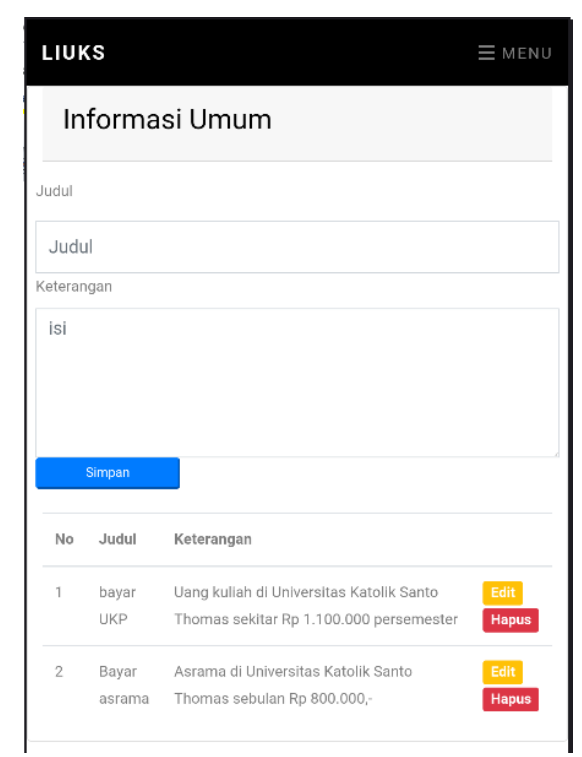

Gambar 9. Halaman Utama Admin 


\section{KESIMPULAN}

Berdasarkan analisis dan hasil pembahasan dapat dirumuskan kesimpulan sebagai berikut:

1. Sistem yang dibangun bisa digunakan untuk memberikan keluhan, memberikan informasi dan menerima informasi.

2. Metode yang digunakan algoritma nazief andriani, algoritma ini mampu mencari kata dasar dari masing masing inputan sehingga dapat menghasilkan output yang terpisah atau dengan kata lain output yang di keluarkan tepat pada sasaran atau pada tujuan.

3. Sistem yang dibangun ini akan mempermudah pengguna untuk mendapatkan informasi yang akurat, efisien dan tidak membutuhkan waktu yang relatif lama sehingga menyebabkan pelayanan yang lambat, terbatas dan tidak responsif dalam memberikan jawaban.

4. Pada sistem pelayanan informasi yang dibangun ini menggunakan algoritma Nazief Andriani dan masih sederhana, bagi peneliti selanjutnya dapat mengembangkan sistem ini dengan algoritma lain, sehingga sistem ini dapat memberikan layanan yang lebih baik.

\section{DAFTAR PUSTAKA}

[1] D. Wahyudi, T. Susyanto, and D. Nugroho, "Implementasi Dan Analisis Algoritma Stemming Nazief \& Adriani Dan Porter Pada Dokumen Berbahasa Indonesia," J. Ilm. SINUS, vol. 15, no. 2, pp. 49-56, 2017, doi: 10.30646/sinus.v15i2.305.

[2] piptools.net, "Stemming Nazief \& Andriani ," piptools.net/stemming-nazief-andriani, 2017. [Online]. Available: https://piptools.net/stemming-nazief-andriani/. [Accessed: 01-May-2020].

[3] T. Limbong and A. H. Hasugian, “Aplikasi e-Directory Berkas Tridharma Kinerja Dosen,” J. Tek. Inform. UNIKA St. Thomas, vol. 1, no. 2, pp. 42-47, 2016.

[4] T. Limbong, "Pemanfaatan visualisasi dan animasi untuk kegiatan akademik sebagai sarana pengumuman pada stmik budi darma medan," Inf. dan Teknol. Ilm., 2013.

[5] T. Limbong and J. Simarmata, "Menentukan Matakuliah yang Efektif Belajar Daring (Belajar dan Ujian) dengan Metode MultiAttribute Utility Theory (MAUT)," J. Resti, vol. 4, no. 2, pp. 370-376, 2020.

[6] I. K. Sudarsana et al., "Paradigma Pedidikan Bermutu Berbasis Teknologi Pendidikan," Jayapangus Press Books, vol. 0, no. 0, Mar. 2018.

[7] J. Simarmata, M. Iqbal, and I. N. Nasution, “Tren dan Aplikasi: Strategi dan Inovasi Dalam Pembelajaran.” Denpasar: Jayapangu s Press, 2019.

[8] liyantanto, "Stemming Bahasa Indonesia dengan Algoritma Nazief dan Andriani | neW_Line," liyantanto.wordpress.com, 2011. [Online]. Available: https://liyantanto.wordpress.com/2011/06/28/stemming-bahasa-indonesia-dengan-algoritma-nazief-danandriani/. [Accessed: 01-May-2020].

[9] A. Masruri, "KUALITAS PELAYANAN PERPUSTA KAAN ( Studi Kasus pada Perpustakaan IAIN Sunan Kalijaga yogyakarta )," Berk. Ilmu Perpust. dan Inf., vol. 1, no. 2, 2004.

[10] Sugiyono, Metode Penelitian Kuantitatif, Kualitatif dan R\&D. Bandung: PT Alfabet, 2016.

[11] S. A. Abdurrasyid and Suyanto, "Implementasi dan optimasi algoritma nazief dan adriani untuk stemming dokumen bahasa indonesia," Universtas Telkom, pp. 1-8, 2012. 